\title{
The Relationship Between Fetuin-A and Bone Mineral Density in Postmenopausal Osteoporosis
}

\author{
Postmenapozal Osteoporozda Fetuin-A ve Kemik Mineral Yoğunluğu Arasındaki İlişki
}

\author{
Aylin SARI, ${ }^{1}$ Turan USLU ${ }^{2}$ \\ ${ }^{1}$ Department of Physical Medicine and Rehabilitation, Erenköy Physical Medicine and Rehabilitation Hospital, İstanbul, Turkey \\ ${ }^{2}$ Department of Physical Medicine and Rehabilitation, Fatih Sultan Mehmet Training and Research Hospital, İstanbul, Turkey
}

Objectives: This study aims to evaluate the relationship between fetuin-A and bone mineral density (BMD) in postmenopausal women.

Patients and methods: Between November 2009 and March 2010, 90 participants were enrolled in the study and divided into three groups including 30 patients in each group. Group 1 consisted of patients who were newly diagnosed with postmenopausal osteoporosis, group 2 consisted of patients who were previously diagnosed with postmenopausal osteoporosis and received treatment, and the control group consisted of healthy volunteers with normal postmenopausal $B M D$ values. Serum fetuin-A level was measured using an enzyme-linked immunosorbent assay (ELISA). Anteriorposterior (AP) lumbar spine, femur neck and total femur BMD were evaluated using dual energy $\mathrm{X}$-ray absorptiometry.

Results: A statistically significant relationship was observed between serum fetuin-A levels and BMD scores. As AP lumbar spine, femur neck and total femur BMD values the fetuin-A levels became lower, serum fetuin- $A$ level decreased. Serum fetuin-A level was lower in patients with postmenopausal osteoporosis, compared to the control group. Serum fetuin-A was not affected by osteoporosis treatment in these patients.

Conclusion: Our study results confirm that BMD parameters are associated with fetuin-A and therefore postmenopausal osteoporosis and fetuin-A. Fetuin-A, a marker for bone mineralization, can be used as a biomarker in the diagnosis and treatment of postmenopausal osteoporosis.

Key words: Bone mineral density; fetuin-A; postmenopausal osteoporosis.
Amaç: Bu çalışmada postmenapozal kadınlardaki serum fetuin-A konsantrasyonları ile kemik mineral yoğunluğu (KMY) değerleri arasındaki ilişki değerlendirildi.

Hastalar ve yöntemler: Kasım 2009 - Mart 2010 tarihleri arasında 90 katılımcı çalışmaya dahil edildi ve otuzar kişilik üç gruba ayrıldı. Grup 1 yeni postmenopozal osteoporoz tanısı konmuş hastalardan, grup 2 postmenopozal osteoporoz tanısı daha önce konmuş ve tedavi edilen hastalardan ve kontrol grubu postmenopozal KMY değerleri normal olan sağlıklı gönüllülerden oluşuyordu. Serum fetuin-A düzeyi, enzim bağlı immünosorbent assay (ELISA) kullanılarak ölçüldü. Ön arka lomber omurga, femur boynu ve total femur KMY dual enerji X-ray absorbsiyometri (DXA) kullanılarak değerlendirildi.

Bulgular: Serum fetuin-A düzeyleri ile KMY skorları arasında istatistiksel olarak anlamlı bir ilişki izlendi. Ön arka lomber omurga, femur boyun ve total femur KMY değerleri azaldıkça serum fetuin-A düzeyi de azalmakta idi. Postmenopozal osteoporozlu hastalarda serum fetuin-A düzeyi, kontrol grubuna kıyasla, daha düşük bulundu. Osoporoz tedavisinin bu hastalarda serum fetuin-A düzeyini etkilemediği görüldü.

Sonuç: Çalışma bulgularımız, KMY parametreleri ile fetuin-A ilişkisini ve dolayısıyla postmenopozal osteoporoz ile fetuin-A arasındaki ilişkiyi doğrulamıştır. Kemik mineralizasyonunu gösteren fetuin-A, postmenopozal osteoporozun tanı ve tedavisinde kullanılabilecek bir biyobelirteç olabilir.

Anahtar sözcükler: Kemik mineral yoğunluğu; fetuin-A; Postmenopozal osteoporoz. 
Osteoporosis is a systemic skeletal disease that is characterized by low bone mass and deterioration of bone tissue that results from increased bone fragility and fracture risk. ${ }^{[1]}$

Loss of bone strength significantly affects the risk of bone fracture, and fractures that lead to pain and loss of function adversely affect quality of life (QoL). Fragility fractures in osteoporosis can add to a pateint's already decreased mobility and increase the need for hospitalization and home care. Low bone mineral density (BMD) and advanced age are the leading factors that lead to a higher risk of osteoporotic fractures. ${ }^{[2]}$

The glycoprotein fetuin-A [a-2-Heremans-Schmid glycoprotein (AHSG)], which was first described by Pedersen in 1944 is a non-collagenous protein that is stored in mineralized bone and teeth. Fetuin-A is synthesized in hepatocytes, ${ }^{[3]}$ and is a negative acute-phase reactant. ${ }^{[4]}$ In addition, recent studies have shown that during fetal life, fetuin-A is a major component of the non-collagenous bone matrix. ${ }^{[5]}$ Normal fetuin-A serum concentrations range between 0.5 and $1.0 \mathrm{~g} / \mathrm{L}$ and decrease with inflammation. ${ }^{[4]}$

Studies have also shown that fetuin-A can inhibit transforming growth factor beta (TGF- $\beta$ )/bone morphogenic protein (BMP) activity. ${ }^{[6]}$ In the absence of fetuin-A, inhibition of TGF- $\beta / B M P$ occurs, and osteogenesis is subsequently stimulated. ${ }^{[7]}$ Thus, the decrease in fetuin-A serum levels with respect to the metabolism of bone through osteoblast apoptosis and the TGF- $\beta$ /BMP system can lead to osteo-inductive effects. Additionally, bone histomorphometric evaluations of either bone formation or bone resorption parameters have shown reduced levels of fetuin-A during these processes. $^{[8]}$ In hemodialysis patients, low fetuin-A concentrations are associated with increased cardiovascular disease, low BMD, and increased mortality. ${ }^{[5]}$

Although fetuin-A supports bone mineralization, the relationship between it and BMD has not been clearly understood. Hence, the aim of our study was to evaluate the relationship between serum fetuin-A concentrations and BMD parameters in postmenopausal women.

\section{PATIENTS AND METHODS}

Ninety postmenopausal women who were treated at the Fatih Sultan Mehmet Training and Research Hospital Physical Therapy and Rehabilitation Clinic, Osteoporosis Department between November
2009 and March 2010 were enrolled in the present study. Approval was obtained from the local ethics committee, and the patients gave their informed written consent for inclusion in the study. The participants were divided into three groups of 30 patients each. Group 1 included patients who were diagnosed for the first time with postmenopausal osteoporosis, group 2 was composed of patients with postmenopausal osteoporosis who were already undergoing treatment, and the control group was comprised of patients with normal BMD levels. The size of our samples was calculated by power analysis, and 45 participants were found to be suitable for each group. However, during the study period, we were only able to confirm a total of 30 eligible patients per group who met our inclusion criteria.

Our patients needed to be postmenopausal (no menstruation for at least one year) women who had osteoporosis in accordance with the World Health Organization (WHO) criteria. In addition, they had to be independently mobile, and have no disease that caused secondary osteoporosis (OP), such as immobilization, metabolic or endocrine disorders, neuromuscular diseases, collagen disease, gastric surgery, malabsorption syndromes, or liver or kidney diseases. A diagnosis of osteoporosis was based on a BMD measurement that was 2.5 standard deviations (SDs) below the typical peak bone mass of a young healthy woman (i.e., the T score was less than $-2.5 \mathrm{SD}$ ).

Study participants were excluded if there was acute infection, malignancy, myocardial infarction (MI) within the previous month, a history of severe trauma, surgery, burns, diabetes mellitus (DM), liver or kidney disease, hormone replacement therapy (HRT) fields, a history of smoking or alcoholism, or fragility fractures. Additionally, any patients who were taking steroids were also excluded from the study.

The following patient information was included in our records: age, gender, occupation, education, clothing, activity, height, weight, age at menopause, smoking and alcohol usage, substance abuse, nutrition, exercise habits, DM status, the presence of any disease affecting bone metabolism, and current medications.

\section{Biochemical analysis}

The following parameters were recorded during the examination: the erythrocyte sedimentation rate (ESR) $(\mathrm{mm} / \mathrm{h})$, C-reactive protein (CRP) levels $(\mathrm{mg} / \mathrm{L})$, a hemogram, total serum calcium $(\mathrm{Ca})$ and phosphorus $(\mathrm{P})$ concentrations $(\mathrm{mg} / \mathrm{dL})$, alkaline 
phosphatase (ALP) levels (U/L), glucose levels (mg/dL), transaminase levels (U/L), blood urea nitrogen (BUN) levels $(\mathrm{mg} / \mathrm{dL})$, creatinine levels $(\mathrm{mg} / \mathrm{dL})$, total protein levels $(\mathrm{mg} / \mathrm{dL})$, albumin levels $(\mathrm{mg} / \mathrm{dL})$, parathyroid hormone $(\mathrm{PTH})$ levels $(\mathrm{pg} / \mathrm{mL})$, serum 25-hydroxyvitamin D3 [25 $(\mathrm{OH}) \mathrm{D} 3]$ concentrations $(\mathrm{ng} / \mathrm{mL})$, and serum fetuin-A concentrations $(\mathrm{ng} / \mathrm{mL})$.

For fetuin-A measurements, venous blood samples were taken after fasting for 10-12 hours, and the serum was separated and stored at $-20{ }^{\circ} \mathrm{C}$. Serum fetuin-A concentrations were measured using an enzyme-linked immunosorbent assay (ELISA) kit for human fetuin-A (Biovendor Laboratory Medicine, Inc., Brno, Czech Republic). A radioimmunoassay coated tube (RIA CT) kit (Biosource Europe SA, Nivelles, Belgium) was used to measurement 25(OH)D3, with normal levels b defined as higher than $30 \mathrm{ng} / \mathrm{mL}$. Parathyroid hormone (PTH) levels were evaluated by the UniCel DxI ${ }^{\otimes} 800$ Immunoassay system (Beckmann Coulter, Inc., Brea, CA, USA), with reference ranges from 20-65 pg/mL. In addition, the Westergren method was utilized to the ESR, and an immunoturbideimetric method was used to evaluate the CRP. The reference ranges for the ESR and CRP were $0-30 \mathrm{~mm} / \mathrm{h}$ and $0-0.5 \mathrm{mg} / \mathrm{L}$, respectively.

\section{Bone mineral density}

The Hologic QDR-2000 Bone Densitometer (Hologic, Inc., Bedford, MA, USA) was employed in our study to measure bone density, and the anteriorposterior (AP) lumbar spine and femoral region were also examined. All assessments were performed at the Fatih Sultan Mehmet Training and Research Hospital Department of Radiology, Bone Mineral Densitometry Unit.

\section{Statistical analysis}

Statistical analyses were performed using the NCSS 2007 software package (NCSS LLC,
Kaysville, UT, USA). The statistical hypothesis for the normality of distribution was tested for all quantitative parameters, and the arithmetic mean (M) and standard deviation (SD) were calculated to describe the parameters with normal distributions. Descriptive statistical methods ( $M$ and SD) as well as subgroup comparisons between groups, one-way analysis of variance (ANOVA), Tukey's multiple comparison test, a chi-square test for qualitative comparisons, and Pearson's correlation test were used to examine the differences between groups. The results were considered to be statistically significant at a value of $\mathrm{p}<0.05$.

\section{RESULTS}

The demographic characteristics of groups 1 and 2 along with the control group including age, weight, height, body mass index (BMI), and age at menopause, are shown in Table 1.

A significant difference was observed in the mean weight, mean height, and mean BMI among the three groups $(p=0.0001)$. The mean weight of the control group was found to be higher than in groups 1 and 2 ( $p=0.007, p=0.0001$, respectively), but there was no significant difference between the two osteoporotic groups $(\mathrm{p}>0.05)$. In addition, the mean height of the control group was higher than what was found in group $2(\mathrm{p}=0.006)$, but no significant difference was observed between the groups 1 and $2(p>0.05)$. Furthermore, the mean BMI of the control group was higher than it was for the two groups of patients with osteoporosis $(\mathrm{p}=0.038, \mathrm{p}=0.001$, respectively), but there was also no significant difference between the groups 1 and 2 themselves ( $p>0.05$ ). Moreover, no statistically significant differences were observed in the mean age and mean age at menopause in groups 1 and $2(\mathrm{p}=0.117, \mathrm{p}=0.479)$.

The biochemical parameters and serum fetuin-A levels of all three groups are shown in Table 2.

\begin{tabular}{|c|c|c|c|c|c|}
\hline & Group 1 & Group 2 & Control & $\mathrm{F} ¥$ & $\mathrm{p}^{\star}$ \\
\hline & Mean \pm SD & Mean \pm SD & Mean \pm SD & & \\
\hline Age (years) & $62.03 \pm 9.52$ & $63.93 \pm 8.14$ & $59.13 \pm 19.08$ & 2.19 & 0.117 \\
\hline Weight (kg) & $70.2 \pm 13.37$ & $64.63 \pm 10.25$ & $79.8 \pm 11.96$ & 12.41 & 0.0001 \\
\hline Height $(\mathrm{cm})$ & $157.7 \pm 6.24$ & $155.3 \pm 5.34$ & $160.07 \pm 6$ & 4.94 & 0.009 \\
\hline Body mass index $\left(\mathrm{kg} / \mathrm{m}^{2}\right)$ & $28.25 \pm 5.21$ & $26.77 \pm 3.8$ & $31.16 \pm 4.44$ & 7.34 & 0.001 \\
\hline Age at menopause (years) & $43.83 \pm 7.44$ & $44.33 \pm 5.77$ & $45.73 \pm 5.38$ & 0.74 & 0.479 \\
\hline
\end{tabular}


Table 2. Mean biochemical parameters and fetuin-A levels of group 1, group 2, and the control group

\begin{tabular}{|c|c|c|c|c|c|}
\hline & $\frac{\text { Group } 1}{\text { Mean } \pm \text { SD }}$ & $\frac{\text { Group } 2}{\text { Mean } \pm \text { SD }}$ & $\frac{\text { Control }}{\text { Mean } \pm \text { SD }}$ & $\mathrm{F} ¥$ & $\mathrm{p}^{*}$ \\
\hline 25(OH)D3 (ng/mL) & $15.02 \pm 8.32$ & $16.04 \pm 8.46$ & $20.38 \pm 6.95$ & 3.85 & 0.025 \\
\hline Parathyroid hormone $(\mathrm{pg} / \mathrm{mL})$ & $127.63 \pm 70.51$ & $112.42 \pm 37.42$ & $98.25 \pm 35.51$ & 2.55 & 0.084 \\
\hline Erythrocyte sedimentation rate $(\mathrm{mm} / \mathrm{hr})$ & $21 \pm 10.28$ & $16.8 \pm 12.7$ & $18.27 \pm 10.93$ & 1.06 & 0.351 \\
\hline Alkaline phosphatase (U/L) & $64.27 \pm 16.06$ & $49.4 \pm 15.65$ & $58.43 \pm 13.33$ & 7.42 & 0.001 \\
\hline C-reactive protein $(\mathrm{mg} / \mathrm{L})$ & $0.46 \pm 0.32$ & $0.48 \pm 0.44$ & $0.52 \pm 0.4$ & 0.22 & 0.802 \\
\hline Fetuin-A (ng/mL) & $64.25 \pm 11.26$ & $65.21 \pm 12.36$ & $74.36 \pm 18.47$ & 4.51 & 0.013 \\
\hline
\end{tabular}

A significant association was found regarding the mean fetuin-A concentrations ( $p=0.0001)$, with the control group having significantly higher levels than groups 1 and 2. However, no significant difference was observed between the two osteoporotic groups $(\mathrm{p}>0.05)$. A significant difference was also noted between the mean value of serum 25(OH)D3 in the control group $(p=0.025)$ was higher than for either group 1 $(\mathrm{p}=0.019)$ or group $2(\mathrm{p}=0.014)$, but no statistically significant difference was observed between the two osteoporotic groups ( $\mathrm{p}>0.05)$.

The relationships between the BMD scores and serum fetuin-A concentrations are shown in Figure 1. Statistically significant relationships were found between the fetuin-A concentration and lumbar AP $\mathrm{T}$ and $\mathrm{Z}$ scores $(\mathrm{r}=0.372, \mathrm{p}=0.0001$ and $\mathrm{r}=0.34$, $\mathrm{p}=0.001$, respectively), femur total $\mathrm{T}$ and $\mathrm{Z}$ scores $(\mathrm{r}=0.338, \mathrm{p}=0.001$ and $\mathrm{r}=0.302, \mathrm{p}=0.004$, respectively $)$, and femoral neck $\mathrm{T}$ and $\mathrm{Z}$ scores $(\mathrm{r}=0.288, \mathrm{p}=0.006$ and $\mathrm{r}=0.247, \mathrm{p}=0.019)$.

A statistically significant correlation was also observed between the serum fetuin-A concentrations and age $(\mathrm{r}=-0.218, \mathrm{p}=0.0039)$.

\section{DISCUSSION}

Osteoporosis is a rapidly increasing healthcare problem associated with an aging population base that continues to grow. ${ }^{[9]}$ Although many risk factors have been identified, details of the physiopathology of this bone disease have not been clearly addressed. In vivo and in vitro studies have helped to further understand bone biology and identify the factors that are associated with this common disease that affects bone metabolism. Although recent in vivo studies have supported a role for the fetuin-A glycoprotein in

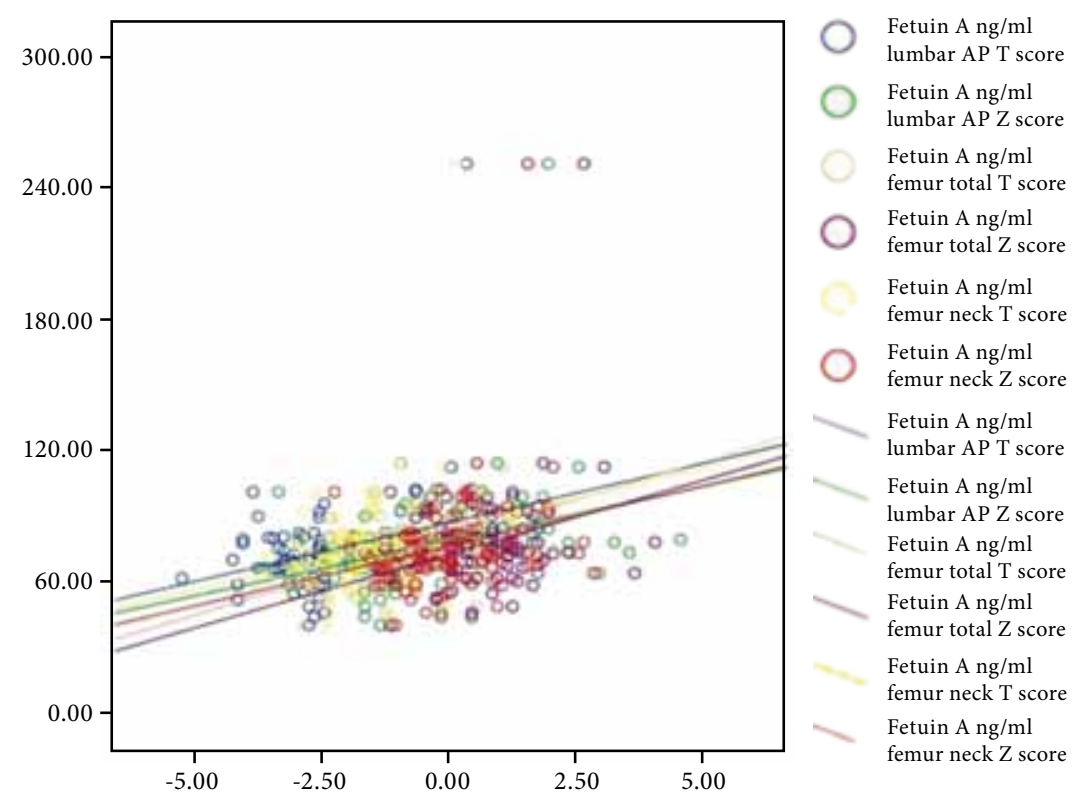

Figure 1. Relationship between fetuin-A concentrations and bone mineral density scores. 
regulating bone mineralization, its function has not been completely described. ${ }^{[10-20]}$

Fetuin-A is a glycoprotein that is associated with bone formation and remodeling. ${ }^{[21,22]}$ Previous studies have shown a correlation between serum $\mathrm{Ca}$ and serum fetuin-A concentrations during bone development in animal models. ${ }^{[23]}$ Fetuin- $\mathrm{A}$ is a major component of the non-collagenous bone matrix during fetal life, and it affects bone growth and remodeling by antagonizing the effects of TNF- $\beta$ / BMP. ${ }^{[7]}$ In vivo studies have also demonstrated a difference in the serum fetuin-A concentrations in patients with Paget's disease, ${ }^{[24]}$ and those with osteogenesis imperfecta, ${ }^{[25]}$ compared with those found in healthy controls.

One of the important functions of fetuin-A is that it inhibits calcium phosphate (Ca-P) precipitation. ${ }^{[26]}$ In addition, fetuin-A inhibits the formation of apatite in in vitro osteoblast cultures. ${ }^{[27]}$ Furthermore, in vitro studies in primary rat calvarias cells have shown that fetuin-A inhibits mineralization by blocking basic Ca-P precipitation and regulating the formation of apatite during this process. ${ }^{[28]}$

Furthermore, a fetuin-deficient mouse study showed that in instances of hypocalcemia, increased bone calcification was observed in individuals with renal failure in the high-risk group for vascular calcification, and that their serum fetuin-A concentrations were very low. ${ }^{[29]}$

Fetuin-A also plays a more general role in mineral metabolism. Studies with fetuin-A gene-ablated mice showed an irregularity of bone mineralization that reinforced the role of fetuin-A in this process. ${ }^{[6,30]}$ Moreover, in patients with end-stage renal failure with fetuin-A deficiency, decreased concentrations of $\mathrm{Ca}$ and $\mathrm{P}$ against increased osteoblast apoptosis have been suggested to have a negative effect on bone structure. $^{[6]}$

A study by Binkert et al. ${ }^{[21]}$ showed that in bone marrow cultures of rats treated with a high dose of dexamethasone, fetuin-A and TNF- $\beta$ suppressed bone alkaline phosphatase, osteopontin, type I collagen, and bone sialoprotein. In recent years, studies have also shown that fetuin-A is a potent inhibitor of calcification that prevents Ca-P precipitation. ${ }^{[26,29,31,32]}$

Vascular calcification is a problem often observed in patients with osteoporosis. Common risk factors and mechanisms that cause bone loss and vascular calcification include aging, estrogen deficiency, vitamin $\mathrm{D}$ and $\mathrm{K}$ abnormalities, chronic inflammation, and oxidative stress (OS). ${ }^{[11]}$ The relationship between BMD and vascular calcification has been previously demonstrated, and many studies have examined fetuin-A concentrations within the framework of this relationship. ${ }^{[8,11-18]}$ Kirkpantur et al. ${ }^{[12]}$ investigated the relationship between BMD parameters, coronary artery calcification (CAC), and serum fetuin-A concentrations in a group of patients who had participated in a hemodialysis (HD) program, and the proximal radius, femoral trochanter, and lumbar spine $\mathrm{T}$ scores were found to be lower in the patients with low serum fetuin-A levels.

In the present study, we found relationships between the spine, total femur, and femoral neck $\mathrm{T}$ scores with serum fetuin-A concentrations, and these scores decreased in conjunction with the lower concentrations of fetuin-A in postmenopausal osteoporosis patients. We also found that the mean fetuin-A concentration of the osteoporotic groups was lower than that of the control group with normal BMD. In addition, we determined that the serum fetuin-A concentration was not affected by whether the postmenopausal osteoporosis patient was undergoing treatment. Taken as a whole, our results indicate that serum fetuin-A concentrations were lower in the patients with postmenopausal osteoporosis than in the controls. In addition, we noted that the BMD scores became lower as the serum fetuin-A values decreased and that the treatment of postmenopausal osteoporosis did not affect the serum levels of fetuin-A. Moreover, we discovered that serum fetuin-A values decreased with as the patients got older.

The low concentration of fetuin-A in postmenopausal women with osteoporosis suggests that it may play a role in the formation and development of this disease. Our findings were consistent with in vitro studies that have shown that fetuin-A may regulate bone mineralization in women. ${ }^{[23-32]}$

Several previous studies also indicated a relationship between fetuin-A levels and BMD, but to our knowledge, only two studies directly evaluated the relationship between fetuin-A levels and BMD without the presence of any disease (i.e., end-stage renal disease or cardiovascular disease).$^{[12-14]}$

A previous study by Ix et al. ${ }^{[15]}$ also investigated the relationship between serum fetuin-A concentrations and BMD in a study group that included a total of 580 Caucasian and African-American participants 
(257 females and 251 males; age range 70-79 years). Their serum fetuin-A concentrations were measured using the ELISA method, and the BMD was measured in the proximal femur, total femur, AP lumbar spine, and whole body using dualenergy X-ray absorptiometry (DXA). Among the women, high serum fetuin-A concentrations were associated with total femur, AP lumbar spine, and whole body BMD; however, in the male group, no relationship was found. In our study, we found a significant correlation between the serum fetuin-A concentrations and femoral neck BMD, but we did not use whole body DXA measurements. A notable difference between their study and ours was the participant groups. Ix et al. ${ }^{[15]}$ enrolled both male and female participants in their study while we only evaluated postmenopausal women. In spite of this difference, most of their findings were in accordance with our findings.

Another recent study by Chailurkit et al. ${ }^{[33]}$ examined the relationships between serum fetuin-A concentration, serum lactoferrin concentration, and bone density in elderly women, and they reported a significant association between serum fetuin-A concentrations and L2-L4 BMD, which is consistent with the results of our study.

Postmenopausal osteoporosis is characterized by low levels of estrogen and high levels of bone mineralization markers. Likewise Rasul et al. ${ }^{[17]}$ showed that fetuin-A has a positive correlation with estrogen and a negative correlation with C-Terminal cross-linked telopeptide of type I collagen (CTX), a bone mineralization marker.

When the aforementioned results are taken into account we believe that our study further demonstrates the relationship between osteoporosis and fetuin-A. Although fetuin-A blocks the TGF- $\beta$ /BMP system to inhibit osteogenesis, fetuin-A may affect the role of other regulatory mechanisms with regard to bone metabolism conferred through osteoblasts, osteoclasts, or other bone cells. With that in mind, new in vivo and in vitro studies should be performed to elucidate the mechanisms that underlie these pathways.

One constraint of this study was that the sample sizes of the three groups was limited by the number of participants who met our study criteria. Therefore, future studies should conducted with a larger sample size to confirm our data.

\section{Conclusion}

Our findings demonstrated a correlation between BMD parameters and fetuin-A, thus establishing that there is a relationship between postmenopausal osteoporosis and fetuin-A. This marker for bone mineralization can therefore be used as a biochemical parameter within the scope of the diagnosis and treatment of postmenopausal osteoporosis. However, based on the bone fractures that we found, future comprehensive research is still needed.

\section{Declaration of conflicting interests}

The authors declared no conflicts of interest with respect to the authorship and/or publication of this article.

\section{Funding}

The authors received no financial support for the research and/or authorship of this article.

\section{REFERENCES}

1. Assessment of fracture risk and its application to screening for postmenopausal osteoporosis. Report of a WHO Study Group. World Health Organ Tech Rep Ser 1994;843:1-129.

2. Reginster JY, Burlet N. Osteoporosis: a still increasing prevalence. Bone 2006;38:S4-9.

3. Ketteler M, Wanner C, Metzger T, Bongartz P, Westenfeld $\mathrm{R}$, Gladziwa U, et al. Deficiencies of calcium-regulatory proteins in dialysis patients: a novel concept of cardiovascular calcification in uremia. Kidney Int Suppl 2003;S84-7.

4. Lebreton JP, Joisel F, Raoult JP, Lannuzel B, Rogez JP, Humbert G. Serum concentration of human alpha 2 HS glycoprotein during the inflammatory process: evidence that alpha 2 HS glycoprotein is a negative acute-phase reactant. J Clin Invest 1979;64:1118-29.

5. Heiss A, DuChesne A, Denecke B, Grötzinger J, Yamamoto K, Renné T, et al. Structural basis of calcification inhibition by alpha 2-HS glycoprotein/ fetuin-A. Formation of colloidal calciprotein particles. J Biol Chem 2003;278:13333-41.

6. Adams CS, Mansfield K, Perlot RL, Shapiro IM. Matrix regulation of skeletal cell apoptosis. Role of calcium and phosphate ions. J Biol Chem 2001;276:20316-22.

7. Demetriou M, Binkert C, Sukhu B, Tenenbaum HC, Dennis JW. Fetuin/alpha2-HS glycoprotein is a transforming growth factor-beta type II receptor mimic and cytokine antagonist. J Biol Chem 1996;271:12755-61.

8. Coen G, Ballanti P, Balducci A, Grandi F, Manni M, Mantella D, et al. Renal osteodystrophy: alpha-Heremans Schmid glycoprotein/fetuin-A, matrix GLA protein serum levels, and bone histomorphometry. Am J Kidney Dis 2006;48:106-13.

9. Walker-Bone K, Dennison E, Cooper C. Epidemiology of osteoporosis. Rheum Dis Clin North Am 2001;27:1-18. 
10. Denecke B, Gräber S, Schäfer C, Heiss A, Wöltje M, Jahnen-Dechent W. Tissue distribution and activity testing suggest a similar but not identical function of fetuin-B and fetuin-A. Biochem J 2003;376:135-45.

11. Hofbauer LC, Brueck CC, Shanahan CM, Schoppet M, Dobnig H. Vascular calcification and osteoporosis--from clinical observation towards molecular understanding. Osteoporos Int 2007;18:251-9.

12. Kirkpantur A, Altun B, Hazirolan T, Akata D, Arici M, Kirazli S, et al. Association among serum fetuin-A level, coronary artery calcification, and bone mineral densitometry in maintenance hemodialysis patients. Artif Organs 2009;33:844-54.

13. Janckila AJ, Lederer ED, Price BA, Yam LT. Tartrateresistant acid phosphatase isoform $5 \mathrm{a}$ as an inflammation marker in end-stage renal disease. Clin Nephrol 2009;71:387-96.

14. Fiore CE, Celotta G, Politi GG, Di Pino L, Castelli Z, Mangiafico RA, et al. Association of high alpha2Heremans-Schmid glycoprotein/fetuin concentration in serum and intima-media thickness in patients with atherosclerotic vascular disease and low bone mass. Atherosclerosis 2007;195:110-5.

15. Ix JH, Wassel CL, Bauer DC, Toroian D, Tylavsky FA, Cauley JA, et al. Fetuin-A and BMD in older persons: the Health Aging and Body Composition (Health ABC) study. J Bone Miner Res 2009;24:514-21.

16. Yilmaz Y. Review article: non-alcoholic fatty liver disease and osteoporosis--clinical and molecular crosstalk. Aliment Pharmacol Ther 2012;36:345-52.

17. Rasul S, Ilhan A, Reiter MH, Todoric J, Farhan S, Esterbauer $\mathrm{H}$, et al. Levels of fetuin-A relate to the levels of bone turnover biomarkers in male and female patients with type 2 diabetes. Clin Endocrinol (Oxf) 2012;76:499-505.

18. Yuce M, Davutoglu V, Cakici M. Fetuin-A, osteoporosis and inflammation--proposal of possible mechanisms for vascular and valvular calcification in chronic kidney disease. Nephrol Dial Transplant 2010; 25:2801.

19. Masi L. Epidemiology of osteoporosis. Clin Cases Miner Bone Metab 2008;5:11-3.

20. Jahnen-Dechent W, Heiss A, Schäfer C, Ketteler M. Fetuin-A regulation of calcified matrix metabolism. Circ Res 2011;108:1494-509.

21. Binkert C, Demetriou M, Sukhu B, Szweras M, Tenenbaum HC, Dennis JW. Regulation of osteogenesis by fetuin. J Biol Chem 1999;274:28514-20.
22. Toroian D, Price PA. The essential role of fetuin in the serum-induced calcification of collagen. Calcif Tissue Int 2008;82:116-26.

23. Colclasure GC, Lloyd WS, Lamkin M, Gonnerman W, Troxler RF, Offner GD, et al. Human serum alpha 2HS-glycoprotein modulates in vitro bone resorption. J Clin Endocrinol Metab 1988;66:187-92.

24. Ashton BA, Smith R. Plasma alpha 2HS-glycoprotein concentration in Paget's disease of bone: its possible significance. Clin Sci (Lond) 1980;58:435-8.

25. Dickson IR, Bagga M, Paterson CR. Variations in the serum concentration and urine excretion of alpha 2HS-glycoprotein, a bone-related protein, in normal individuals and in patients with osteogenesis imperfecta. Calcif Tissue Int 1983;35:16-20.

26. Ketteler M, Bongartz P, Westenfeld R, Wildberger JE, Mahnken AH, Böhm R, et al. Association of low fetuin-A (AHSG) concentrations in serum with cardiovascular mortality in patients on dialysis: a cross-sectional study. Lancet 2003;361:827-33.

27. Schinke T, Amendt C, Trindl A, Pöschke O, Müller-Esterl $\mathrm{W}$, Jahnen-Dechent $\mathrm{W}$. The serum protein alpha2-HS glycoprotein/fetuin inhibits apatite formation in vitro and in mineralizing calvaria cells. A possible role in mineralization and calcium homeostasis. J Biol Chem 1996;271:20789-96.

28. Schafer C, Heiss A, Schwarz A, Westenfeld R, Ketteler M, Floege J, et al. The serum protein alpha 2-Heremans-Schmid glycoprotein/fetuin-A is a systemically acting inhibitor of ectopic calcification. J Clin Invest 2003;112:357-66.

29. Dellegrottaglie S, Sanz J, Rajagopalan S. Molecular determinants of vascular calcification: a bench to bedside view. Curr Mol Med 2006;6:515-24.

30. Reynolds JL, Joannides AJ, Skepper JN, McNair R, Schurgers LJ, Proudfoot D, et al. Human vascular smooth muscle cells undergo vesicle-mediated calcification in response to changes in extracellular calcium and phosphate concentrations: a potential mechanism for accelerated vascular calcification in ESRD. J Am Soc Nephrol 2004;15:2857-67.

31. Jahnen-Dechent W, Schinke T, Trindl A, Müller-Esterl W, Sablitzky F, Kaiser S, et al. Cloning and targeted deletion of the mouse fetuin gene. J Biol Chem 1997;272:31496-503.

32. Price PA, Lim JE. The inhibition of calcium phosphate precipitation by fetuin is accompanied by the formation of a fetuin-mineral complex. J Biol Chem 2003;278:22144-52.

33. Chailurkit L, Kruavit A, Rajatanavin R, Ongphiphadhanakul B. The relationship of fetuin-A and lactoferrin with bone mass in elderly women. Osteoporos Int 2011;22:2159-64. 